\section{Case Reports in Dermatology}

Case Rep Dermatol 2016;8:363-368

DOI: $10.1159 / 000452323$

Publisnea onine:December 13, 2016
(C) 2016 The Author(s)

Published by S. Karger AG, Basel www.karger.com/cde

This article is licensed under the Creative Commons Attribution-NonCommercial 4.0 International License (CC BY-NC) (http://www.karger.com/Services/OpenAccessLicense). Usage and distribution for commercial purposes requires written permission.

\title{
Giant Basal Cell Carcinomas Arising on the Bilateral Forearms of a Patient: A Case Report and Review of Nonsurgical Treatment Options
}

\author{
Sarah Shangraw ${ }^{a}$ Rivka C. Stone ${ }^{b}$ Jeong Hee Cho-Vega ${ }^{c}$ \\ Robert S. Kirsner ${ }^{\text {b }}$ \\ aOregon Health and Science University School of Medicine, Portland, OR, USA; \\ ${ }^{b}$ Department of Dermatology and Cutaneous Surgery, University of Miami Miller School \\ of Medicine, Miami, FL, USA; 'Dermatopathology Service, Department of Pathology, \\ Sylvester Comprehensive Cancer Center and University of Miami Miller School of \\ Medicine, Miami, FL, USA
}

\section{Keywords}

Giant basal cell carcinoma $\cdot$ Nonsurgical treatment $\cdot$ Medical therapy

\begin{abstract}
Giant basal cell carcinomas (GBCCs) are large basal cell carcinomas $(B C C s ;<5 \mathrm{~cm})$ with a greater propensity to invade and metastasize than standard BCCs. The presence of 2 GBCCs in a single individual is rare. We present the case of a 71-year-old Caucasian male with bilateral GBCCs on the dorsal forearms, measuring $130 \mathrm{~cm}^{2}$ and $24 \mathrm{~cm}^{2}$, respectively, that developed over a 21-year period. Over this period, the patient treated the tumors with herbal remedies. Histologic evaluation showed a conventional nodular BCC for both tumors. Computed tomography and magnetic resonance imaging revealed a T4NOMO stage for the larger lesion. Surgical excision and grafting and reconstruction were offered, but he declined. This case highlights a shared belief in holistic treatments and rejection of Western medical inter-
\end{abstract}


ventions that are common among many patients with GBCC. Studies reporting nonsurgical treatments for GBCCs, including radiotherapy, vismodegib, topical imiquimod, and acitretin are reviewed.

(C) 2016 The Author(s)

Published by S. Karger AG, Base

\section{Introduction}

Giant basal cell carcinomas (GBCCs) measuring more than $5 \mathrm{~cm}$ constitute less than $1 \%$ of all basal cell carcinomas (BCCs) [1,2]. Due to their large size and tendency to infiltrate neighboring muscle, nerve, and bone, these lesions are often disfiguring and disabling. The presence of 2 coexisting GBCCs in the same individual is rare, with few reported cases [3-6]. Here we present a patient with 2 GBCCs located symmetrically on the bilateral forearms.

\section{Case Report}

A 71-year-old Caucasian man presented to the emergency room with 2 large tumors symmetrically distributed on his dorsal forearms. The lesions had been growing slowly for 21 years. The patient did not seek medical treatment; instead he opted for home herbal remedies and salves. He also reported gouging out portions to limit tumor growth. The large bleeding lesions were noted when he underwent a routine medical assessment, and he was referred to the hospital for evaluation.

His past medical history was significant for mild dementia. He denied prior exposure to radiation, immunosuppressive medications, and carcinogens. Physical examination was notable for an alert, oriented, cachectic Caucasian man. On the left dorsal forearm there was a $10 \times 13 \times 4.5 \mathrm{~cm}$ exophytic nodular tumor on an ulcerated base. On the right dorsal forearm was a $6 \times 4 \mathrm{~cm}$ ulcerated plaque with rolled borders. Both tumors were friable with hemorrhagic exudate and sclerotic perilesional skin (Fig. 1). No lymphadenopathy was appreciated. Biopsies of both lesions were diagnostic for nodular BCC (Fig. 2). Magnetic resonance imaging of the left forearm tumor revealed local muscle, nerve, and periosteal invasion. Computed tomography scans of the chest, abdomen, and pelvis showed no evidence of nodal involvement or metastatic disease. Superficial wound cultures of both tumors grew Pseudomonas aeruginosa that was treated with intravenous cefepime.

Orthopedic and plastic surgery consultants recommended wide local excision of both tumors followed by skin grafting and reconstruction. The patient consented to removal of the lesions but refused subsequent grafts, stating that they were contrary to his beliefs of natural healing. A psychiatry consult was obtained to assess the patient's ability to make medical decisions, and he was found to have capacity. He was discharged in a stable condition to a rehabilitation facility, with outpatient follow-up arranged to discuss nonsurgical treatment options. 


\section{Discussion}

While BCCs are generally small and slow growing, GBCCs are rare, aggressive tumors that often recur and are more likely to metastasize [7]. Though many risk factors for GBCCs are similar to those for BCCs (e.g., Caucasian race, prior history of BCC, and exposure to ultraviolet radiation), a distinct feature of GBCC is a patient's neglect of the lesion and a resulting delay in effective intervention $[3,5,8,9]$.

A common trend among cases of GBCC is patients' distrust of contemporary Western medicine $[3,5,8]$. Previous case reports of multiple GBCCs also described patients with established beliefs in holistic or religious treatments $[3,5,8]$. In some instances, patients that experienced BCC recurrence after surgical excision were frustrated by the outcome and rejected all further care, leading to progression and death from associated complications [10].

Given the markedly increased risk of metastases and death from GBCC, it is particularly important to recognize and openly address patient concerns regarding treatment options. Establishing a strong physician-patient therapeutic alliance is a critical step in identifying and implementing interventions.

While excision remains the widely acknowledged gold standard of treatment for GBCC $[1,2,7]$, Table 1 summarizes various alternative therapies that have been reported in the medical literature and can be discussed with patients declining first-line surgical modalities [11-15]. Most of these medical therapies are affordable and easily dosed and have an acceptable side effect profile. Treatment involving radiation has historically been reserved for poor surgical candidates [11-13]. Vismodegib is a targeted chemotherapy agent that has been shown to halt tumor growth, but it has many side effects [9]. Finally, imiquimod has been used alone or in combination with cryosurgery or acitretin to successfully shrink GBCCs by an unknown mechanism $[6,14,15]$. In each instance, treating physicians were able to negotiate treatment plans that were consistent with patient beliefs, resulting in compliance and tumor regression.

In conclusion, GBCCs are rare, destructive tumors that are more likely to develop in patients with strong beliefs in complementary and holistic medicine. A discussion and implementation of less invasive alternative therapeutic modalities can be integral to patient survival and improved clinical outcomes.

\section{Statement of Ethics}

We received verbal consent from the patient to use his data and photographs for publication.

\section{Disclosure Statement}

The authors have no financial disclosures to make. 


\section{References}

1 Beahrs OH, Henson DE, Hutter RVP, Meyers MH: American Joint Committee on Cancer. Manual for Staging of Cancer, ed 3. Philadelphia, JB Lippincott, 1988.

2 Betti R, Inselvini E, Moneghini L, Crosti C: Giant basal cell carcinoma: report of four cases and considerations. J Dermatol 1997;24:317-321.

-3 Mainella M, Majewski WT, Latkovich P, Michaels BM: Two giant basal cell carcinomas presenting simultaneously in the same patient, one resulting in lower extremity limb loss. Ann Plast Surg 1998;41:444-447.

-4 Lackey PL, Sargent LA, Wong L, Brzezienski M, Kennedy JW: giant basal cell carcinoma surgical management and reconstructive challenges. Ann Plast Surg 2007;58:250-254.

5 Rieger UM, Schlecker C, Pierer G, Haug M: Spontaneous regression of two giant basal cell carcinomas in a single patient after incomplete excision. Tumori 2009;95:258-263.

-6 Sanmartín V, Aguayo R, Baradad M, Casanova JM: Oral acitretin and topical imiquimod as neoadjuvant treatment for giant basal cell carcinoma (in Spanish). Actas Dermosifiliogr 2012;103:149-152.

-7 Archontaki M, Stavrianos SD, Korkolis DP, Arnogiannaki N, Vassiliadis V, Liapakis IE, Christ H, Rapidis AD, Kokkalis G: Giant basal cell carcinoma: clinicopathological analysis of 51 cases and review of the literature. Anticancer Res 2009;29:2655-2663.

8 Laudenschlager MD, Donelan KJ, Lynch DW, Stephenson PD, Timmerman GL, Jassim AD: Opting for Christian Science vs surgical removal: a case report of a giant basal cell carcinoma arising on the back of a 66-year-old man. SD Med 2011;64:325, 327, 329.

-9 Andersen RM, Lei U: A massive neglected giant basal cell carcinoma in a schizophrenic patient treated successfully with vismodegib. J Dermatol Treat 2015;26:575-576.

10 Desmond B, Boudreaux L, Young J: A rare case of super giant basal cell carcinoma. JAAD Case Rep 2015;1:280-282.

11 Wandrey N, Chen T, Eng T: Dramatic resolution of an unresectable giant basal cell carcinoma treated with intensity-modulated radiation therapy (IMRT) - a case report. Cureus 2015;7:e416.

12 Rossi R, Campolmi P, Giomi B, Massi D, Cappugi P: Giant exophytic basal cell carcinoma treated with radiotherapy. J Eur Acad Dermatol Venerol 2002;16:374-376.

13 Copcu E, Aktas A: Simultaneous two organ metastases of the giant basal cell carcinoma of the skin. Int Semin Surg Oncol 2005;2:1.

$>14$ Jian-De H, Qi-Man L, Yu-Yun Z, Li-Hua C, Chun-Guang M, Cheng T: Successful treatment of giant basal cell carcinoma with topical imiquimod $5 \%$ cream with long term follow-up. Indian J Dermatol 2014;59:575-578.

-15 Heo YS, Yoon JH, Choi JE, Ahn HH, Kye YC, Seo SH: A case of superficial giant basal cell carcinoma with satellite lesions on scalp. Ann Dermatol 2011;23(suppl 1):S111-S115. 


\section{Case Reports in Dermatology}

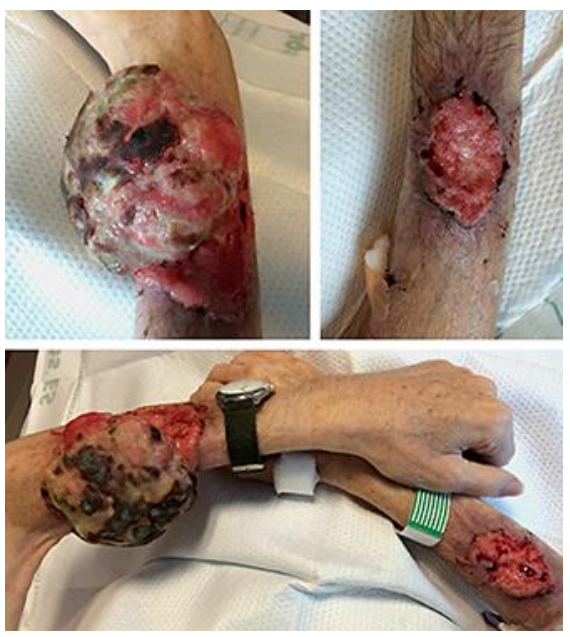

Fig. 1. Fungating, friable tumors on the bilateral forearms.

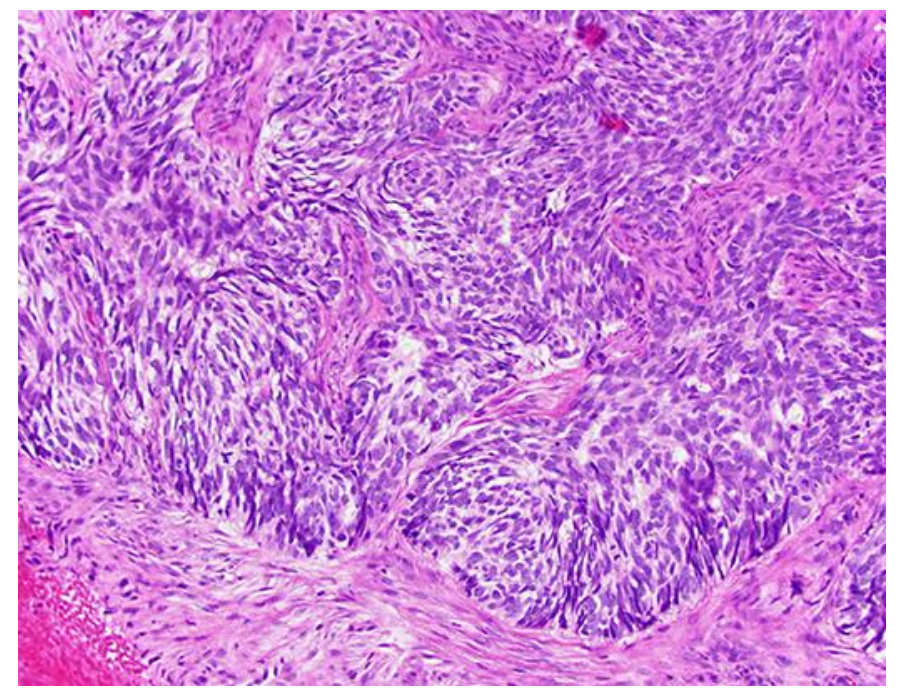

Fig. 2. Representative H\&E stain of biopsies from the right forearm tumor, demonstrating nodular, pseudopalisading basaloid cells in an infiltrative pattern. A stromal reaction was noted in both lesions. 

www.karger.com/cde

Shangraw et al.: Giant Basal Cell Carcinomas Arising on the Bilateral Forearms of a

Patient: A Case Report and Review of Nonsurgical Treatment Options

Table 1. Successful nonsurgical options for unresectable nonmetastatic GBCCs

\begin{tabular}{|c|c|c|c|c|c|c|c|c|}
\hline Treatment & $\begin{array}{l}\text { Patient } \\
\text { age/sex, } \\
\text { years }\end{array}$ & $\begin{array}{l}\text { Reason for } \\
\text { nonsurgical } \\
\text { intervention }\end{array}$ & $\begin{array}{l}\text { Location } \\
\text { and size of } \\
\text { tumor, cm }\end{array}$ & Stage & $\begin{array}{l}\text { Neo- } \\
\text { adju- } \\
\text { vant }\end{array}$ & Treatment details & Outcome & Side effects \\
\hline $\begin{array}{l}\text { Intensity- } \\
\text { modulated } \\
\text { radiation } \\
\text { therapy [11] }\end{array}$ & $59 / \mathrm{M}$ & $\begin{array}{l}\text { Poor surgical } \\
\text { candidate with } \\
\text { COPD, CAD, } \\
\text { epilepsy, HTN }\end{array}$ & $\begin{array}{l}\text { Upper back } \\
10 \times 10\end{array}$ & T4N0M0 & No & $\begin{array}{l}12 \mathrm{MeV} 60 \mathrm{~Gy} \\
\text { total dose, then } \\
9 \mathrm{MeV} 20 \text { Gy over } \\
3 \text { months }\end{array}$ & $\begin{array}{l}\text { Lesion shrunk to } \\
2-3 \mathrm{~cm} \text {; minimal } \\
\text { involvement of deeper } \\
\text { soft tissues; no evi- } \\
\text { dence } \\
\text { of recurrence at } \\
5 \text { months }\end{array}$ & $\begin{array}{l}\text { No significant } \\
\text { side effects }\end{array}$ \\
\hline $\begin{array}{l}\text { Superficial } \\
\text { roentgen } \\
\text { radiotherapy } \\
{[12]}\end{array}$ & $66 / M$ & $\begin{array}{l}\text { Refusal of } \\
\text { surgical } \\
\text { intervention }\end{array}$ & $\begin{array}{l}\text { Shoulder } \\
10 \times 7\end{array}$ & T4N1M0 & No & $\begin{array}{l}160 \mathrm{kV} 150 \mathrm{~Gy} \\
\text { total dose over } \\
10 \text { treatments }\end{array}$ & $\begin{array}{l}\text { No recurrence at } 1 \\
\text { year } \\
\text { and satisfying aesthetic } \\
\text { results }\end{array}$ & $\begin{array}{l}\text { No significant } \\
\text { side effects }\end{array}$ \\
\hline $\begin{array}{l}\text { Chemoradio- } \\
\text { therapy } \\
{[13]}\end{array}$ & $62 / \mathrm{F}$ & $\begin{array}{l}\text { Refusal of } \\
\text { surgical } \\
\text { intervention }\end{array}$ & $\begin{array}{l}\text { Face } \\
5.5 \times 4.5\end{array}$ & T4N1M1 & No & $\begin{array}{l}6,000 \text { cGy total } \\
\text { dose over } \\
3 \text { weeks plus oral } \\
\text { cisplatin and } \\
5 \text {-fluorouracil }\end{array}$ & $\begin{array}{l}\text { No recurrence at } \\
6 \text { months }\end{array}$ & NS \\
\hline $\begin{array}{l}\text { Vismodegib } \\
\text { [9] }\end{array}$ & $59 / \mathrm{M}$ & $\begin{array}{l}\text { Poor surgical } \\
\text { candidate with } \\
\text { COPD, CAD, } \\
\text { epilepsy, HTN }\end{array}$ & $\begin{array}{l}\text { Upper back } \\
10 \times 10\end{array}$ & T4N0M0 & Yes & $\begin{array}{l}\text { Continuous for } \\
11 \text { years }\end{array}$ & $\begin{array}{l}\text { Arrested growth of } \\
\text { tumor }\end{array}$ & $\begin{array}{l}\text { Dysgeusia, } \\
\text { diarrhea, } \\
\text { anorexia }\end{array}$ \\
\hline $\begin{array}{l}\text { Imiquimod } \\
\text { [14] }\end{array}$ & $51 / \mathrm{M}$ & $\begin{array}{l}\text { Unfavorable } \\
\text { location }\end{array}$ & $\begin{array}{l}\text { Cheek } \\
6 \times 8\end{array}$ & T3N0M0 & No & $\begin{array}{l}\text { Applied every } \\
\text { other day for } \\
8-12 \text { h over } \\
12 \text { weeks }\end{array}$ & $\begin{array}{l}\text { No recurrence at } 3 \\
\text { years }\end{array}$ & $\begin{array}{l}\text { Local irritation, } \\
\text { inflammation, } \\
\text { edema after } \\
1 \text { week; resolved } \\
\text { with prednisone } \\
\text { burst and } \\
\text { decreased } \\
\text { application to } \\
\text { every third day }\end{array}$ \\
\hline $\begin{array}{l}\text { Imiquimod- } \\
\text { cryosurgery } \\
\text { combination } \\
{[15]}\end{array}$ & $54 / \mathrm{M}$ & $\begin{array}{l}\text { Patient } \\
\text { reluctance, } \\
\text { and affected } \\
\text { area too large } \\
\text { for flap }\end{array}$ & $\begin{array}{l}\text { Frontal } \\
\text { scalp } \\
6 \times 8\end{array}$ & T3N0M0 & No & $\begin{array}{l}2-3 \text { freeze-thaw } \\
\text { cycles followed } \\
\text { by } \\
5 \% \text { imiquimod } \\
\text { cream after } \\
4 \text { days repeated } \\
\text { monthly for } \\
4 \text { cycles }\end{array}$ & $\begin{array}{l}\text { No recurrence at } \\
9 \text { months }\end{array}$ & NS \\
\hline $\begin{array}{l}\text { Acitretin- } \\
\text { imiquimod } \\
\text { combination } \\
{[6]}\end{array}$ & $\begin{array}{l}68 / \mathrm{F} \\
63 / \mathrm{M}\end{array}$ & $\begin{array}{l}\text { Refusal of } \\
\text { surgical } \\
\text { intervention } \\
\text { Unfavorable } \\
\text { location and } \\
\text { refusal of } \\
\text { surgical } \\
\text { intervention }\end{array}$ & $\begin{array}{l}\text { Chest } \\
18 \times 11 \\
8 \times 4 \\
\text { Cheek } \\
10 \times 7\end{array}$ & NS & Yes & $\begin{array}{l}\text { Daily } 25 \mathrm{mg} / \text { day } \\
\text { oral acitretin and } \\
5 \% \text { imiquimod } \\
\text { cream for } \\
6 \text { months; } \\
\text { eventual surgery } \\
\text { and radiotherapy } \\
\text { (200 cGy in } \\
30 \text { doses), } \\
\text { respectively }\end{array}$ & $\begin{array}{l}\text { No recurrence at } 8 \\
\text { years } \\
\text { No recurrence at } 2 \\
\text { years }\end{array}$ & $\begin{array}{l}\text { Malaise; resolved } \\
\text { with decreased } \\
\text { imiquimod dose } \\
\text { Local } \\
\text { inflammation }\end{array}$ \\
\hline
\end{tabular}

CAD, coronary artery disease; COPD, chronic obstructive pulmonary disease; HTN, hypertension; NS, not specified. 